九州大学学術情報リポジトリ

Kyushu University Institutional Repository

\title{
Molecular Characterization of a New Begomovirus Infecting Honeysuckle in Kobe, Japan
}

Were, Hassan Karakacha

Laboratory of Plant Pathology Divisioin of Plant Pathology and Pesticide Science, Department of Applied Genetics and Pest Management, Faculty of Agriculture, Kyushu University

Takeshita, Minoru

Laboratory of Plant Pathology Divisioin of Plant Pathology and Pesticide Science, Department of Applied Genetics and Pest Management, Faculty of Agriculture, Kyushu University

Furuya, Naruto

Laboratory of Plant Pathology Divisioin of Plant Pathology and Pesticide Science, Department of Applied Genetics and Pest Management, Faculty of Agriculture, Kyushu University

Takanami, Yoichi

Laboratory of Plant Pathology Divisioin of Plant Pathology and Pesticide Science, Department of Applied Genetics and Pest Management, Faculty of Agriculture, Kyushu University

https://doi.org/10.5109/4622

出版情報：九州大学大学院農学研究院紀要. 50 (1)，pp.61-71，2005-02-01. Faculty of Agriculture， Kyushu University

バージョン :

権利関係 : 


\title{
Molecular Characterization of a New Begomovirus Infecting Honeysuckle in Kobe, Japan
}

\author{
Hassan Karakacha WERE, Minoru TAKESHITA, Naruto FURUYA \\ and Yoichi TAKANAMI*
}

\author{
Laboratory of Plant Pathology, Division of Plant Pathology and Pesticide Science, \\ Department of Applied Genetics and Pest Management, Faculty of Agriculture, \\ Kyushu University, Fukuoka 812-8581, Japan \\ (Received November 5, 2004 and accepted November 11, 2004)
}

\begin{abstract}
A virus (HY12) isolated from honeysuckle (Lonicera japonica Thunb.) collected in Kobe, Hyogo prefecture, Japan, showing symptoms of yellow vein mosaic, was characterized. HY12 was transmitted to Nicotiana benthamiana by sap inoculation while the other honeysuckle isolates could not. The complete DNA-A and DNA- $\beta$ like molecules of the isolate were determined and found to comprise 2763 and 1262 nucleotides (nt), respectively, with a typical begomovirus genome organization. The DNA $\beta$ molecule had the conserved ORF $(\beta \mathrm{C} 1)$ and satellite conserved region (SCR) typical of the Geminiviridae family containing a 5'-TAATATTAC-3' motif in the stem loop and the adenine-(A) rich region. Additionally, its entire sequence was interrupted at intervals with sequences that were not viral and whose origin was unknown. A comparison of the DNA-A sequences revealed that $\mathrm{HY} 12$ shared $74 \%$ with four other honeysuckle begomoviruses but $88-89 \%$ with tobacco begomoviruses found in Japan. The isolate shared up to $92 \%$ of the IR sequences with the honeysuckle begomoviruses but only $60-88 \%$ with those of tobacco. Phylogenetic analysis of full length DNA-A component as well as its CP clustered HY12 with the tobacco begomoviruses. HY12 is an isolate of Honeysuckle yellow vein mosaic virus.
\end{abstract}

\section{INTRODUCTION}

Geminiviruses are plant viruses characterized by their bisegmented (geminate) shape and size $(30 \times 20 \mathrm{~nm})$ of their particles, a capsid protein of about $30 \mathrm{kDa}$ and their propensity to infect phloem cells. Each geminate particle encapsidates a small (2.5-3.0 kb) circular single stranded (ss) DNA genome that replicates in the nuclei of host cells via a double stranded (ds) DNA intermediate (replicative form) through a rolling cycle mechanism (Saunders et al., 1991). Based on the host range, genome organization and vector species, the Geminiviridae family is divided into four genera (Rybicki, 1994; Briddon and Markham, 1995; Padidam et al., 1995; Fauquet et al., 2000). Begomovirus comprises over 100 species (Fauquet and Stanley, 2003) and is the only genus that is transmitted by the whitefly Bemisia tabaci (Harrison and Robinson, 1999), infects only dicotyledonous plants and causes most of the economically important diseases of plant species. Members of this genus are mostly bipartite with two components known as DNA-A and DNA-B. Until recently, monopartite begomoviruses were known to have only one DNA component that closely resembles DNA-A of bipartite begomoviruses. Some of the DNA-A like molecules have now been found to associate with yet another molecule referred to as

\footnotetext{
* Corresponding author (E-mail: takanami@agr.kyushu-u.ac.jp)
} 
DNA $\beta$ : DNA $\beta$ depends on the begomovirus for its proliferation and is responsible for accumulation of the helper virus to normal levels in infected plants, suggesting its involvement in either replication, systemic movement or the suppression of host defense mechanism (Sounders et al., 2000).

In Japan, only one begomovirus, Honeysuckle yellow vein mosaic virus (HYVMV) has been reported infecting honeysuckle (Lonicera japonica Thunb.) while three begomoviruses, Tobacco leaf curl Kochi virus (TbLCKV-KK), Tobacco leaf curl Japan virus (TbLCJV), TbLCJV -[JP3], TbLCJV-[JP2] and Tobacco leaf curl Yamaguchi virus (TBLCYV) infect tomato (Ikegami et al., 1987; Onuki, 2003). However, little information is available in the area of genomic recombination and evolution of the Japanese honeysuckle and tobacco begomoviruses. Moreover, it is still not clear whether begomoviruses infecting tobacco are the same ones infecting honeysuckle. To resolve this impasse, we collected samples in Kobe, Hyogo prefecture, Japan and analyzed them by PCR. Based on the results, we report here characterization of a new distinct begomovirus infecting honeysuckle in Kobe, Japan.

\section{MATERIALS AND METHODS}

\section{Sample collection and sap inoculation}

Honeysuckle samples (stem cuttings) showing symptoms of a viral disease (Fig. 1) were collected in Kobe, Hyogo prefecture, Japan in 2000 and labeled HY12. The cuttings were potted and maintained in an insect-free greenhouse kept at $24-27^{\circ} \mathrm{C}$. To determine infectivity of the virus isolate and symptoms induced in Nicotiana benthamiana, and $N$. tabacum, test plant seedlings at the 3- to 5-leaf stage were inoculated by sap obtained by homogenizing infected leaf samples (Table 1 ) in the standard inoculation buffer $[0.05 \mathrm{M}$ $\mathrm{K} / \mathrm{Na}$ phosphate buffer, $\mathrm{pH} 7.5$ containing $2 \%(\mathrm{w} / \mathrm{v})$ polyvinylpyrrolidone (PVP), $0.2 \%$ $\left.(\mathrm{w} / \mathrm{v}) \mathrm{Na}_{2} \mathrm{SO}_{3}\right]$. Leaf homogenates were rubbed on the upper 2-3 caborundum-dusted leaves of the test plants and kept in the greenhouse for symptom development. Virus isolates used for inoculation were HYVMV-HY12, -FK1 (Accession No. in the DNA data bases: AB178945), -OT2 (AB178948) and -SP1 (AB182261).

Table 1. Infectivity of Japanese honeysuckle geminivirus isolates on $N$. benthamiana and $N$. tabacum by sap inoculation.

\begin{tabular}{llcc}
\hline $\begin{array}{l}\text { Sample } \\
\text { origin }\end{array}$ & Strain & $\begin{array}{c}\text { Plants infected } \\
\text { /inoculated }\end{array}$ & $\begin{array}{c}\text { Virus detected in } \\
\text { N. benthamiana/tabacum }\end{array}$ \\
\hline Fukuoka & FK1 & $0 / 10$ & $-/-$ \\
Kobe & HY12 & $6 / 10$ & HYVMV/- \\
Oita & OT2 & $0 / 10$ & $-/-$ \\
Sapporo & SP1 & $0 / 10$ & $-/-$ \\
\hline
\end{tabular}




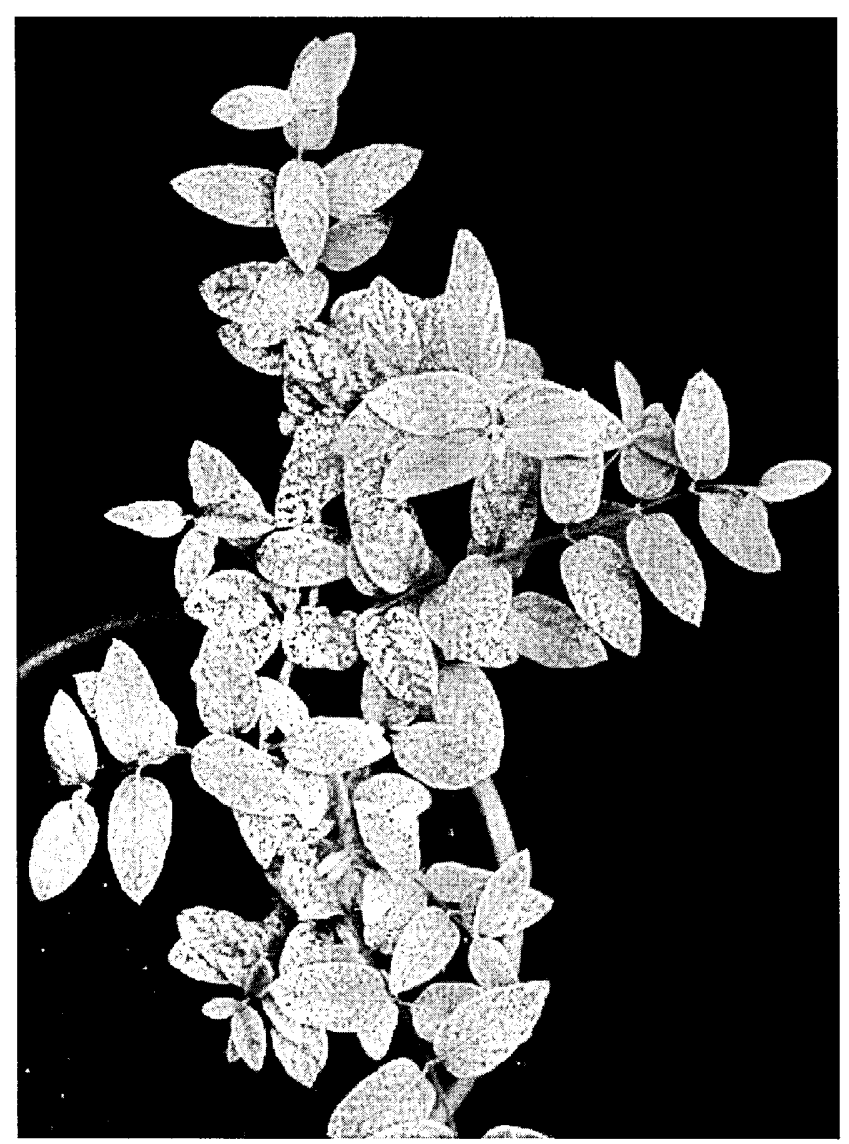

Fig. 1. Begomovirus-infected honeysuckle plant collected in Kobe, Japan showing symptoms of yellow vein mosaic and mottle.

\section{PCR-mediated amplification and cloning of HY12 DNA-A and DNA $\beta$}

Total DNA was extracted from young virus-infected honeysuckle leaves essentially as described by Dellaporta et al. (1983). Amplification of viral sequences was done using degenerate universal geminivirus primers designed by Briddon and Markham (1994). Sequence analysis of the PCR products obtained enabled us to design primers (Table 2) specific for HYVMV and tobacco leaf curl begomoviruses from Japan. For easy amplification and cloning, two primer pairs [HGVU148 // HGVL1560 amplifies 1500 bp (lower DNA-A fragment); REGEU1560 // REGEL148 amplifies 1450 bp (upper DNA-A fragment)] and one primer pair [CHIGu360A // CHIGL360A (amplifies complete DNA-A component) were used. DNA $\beta$ was amplified using universal primers (Briddon et al., 2002). PCR amplification of both components proceeded as described previously (Were, 2001). PCR products of half- and full-length DNA-A as well as full length DNA $\beta$ were purified, cloned into pGEM $^{\mathrm{T}}$ - vector (promega) essentially as described by Sambrook et 
Table 2. Primers used for amplification of honeysuckle geminivirus DNA-A fragments.

\begin{tabular}{llll}
\hline Primer & Sequence (5'-3') & Strand & Target \\
\hline HGVU148 & CGTCTGAACTTCGACGGCCCGTATGTC & Virion & CP \\
HGVL1560 & GCAACACCAAGTACGGGAAACCA & Complementary & AC1 \\
REGEU1560 & TGGTTTCCCGTACTTGGTGTT & Vrion & AC1 \\
REGEL148 & GCTTGTGCCTTGGGCAATGGG & Complementary & CP \\
CHIGU360A & ACTTCGACRGCCCGTATGYC & Virion & CP \\
CHIGL360A & TCAGACGGCGMCGTRCCYTG & Complementary & CP \\
\hline
\end{tabular}

al. (1989). The cloned DNA fragments were sequenced by a commercial company (GreenGene BioTech. Seoul, Korea).

\section{Sequence determination and analysis}

HY12 DNA-A sequence was phylogenetically compared to those of other honeysuckle, tobacco, Eupatorium and tomato using the multiple sequence alignment application of DNAMAN version 4.0 (Lynnon Biosoft, Quebec, Canada) full optimal sequence alignments and neighbor-joining method options of Saitou and Nei (1987) with 1000 bootstrap replications. Percent DNA-A nucleotide (nt) and ORF amino acid (aa) sequence identities between virus isolates were calculated using the distance between all pairs of sequences in the multiple alignments. The begomovirus sequences used for comparison and their database accession numbers were as follows: Honeysuckle yellow vein mosaic virus (HYVMV, AB020781; HYVMV-FK1, AB17845; HYVMV-OT1, AB178947; HYVMV-OT2, AB178948), Tobacco leaf curl Yamaguchi virus (TBLCYV, AB079765), Tobacco leaf curl Japan virus (TbLCJV, AB028604; TbLCJV-JP2, AB055008; TbLCJV-JP3 AB079689), Eupatorium yellow vein virus (EpYVV, AB007990; EpYVV-Yamaguchi, AB079766; EpYVV-MNS2, AJ438936), Tomato leaf curl Taiwan virus (ToLCTV, U88692), Ageratum yellow vein China virus-[Hn2] (AYVCNV-Hn2, AJ495813), Ageratum yellow vein Sri Lanka virus (AYVSLV, AF314144), Malvastrum yellow vein virus-[Y47] (MYVV-Y47, AJ457824), Tomato yellow leaf curl China virus-Tb[Y5] (TYLCCNV-Tb[Y5] AJ319674), Tobacco leaf curl Yunnan virus-[Y3] (TbLCYNV-Y3, AF240674), Tobacco leaf curl Zimbabwe virus (TbLCZV, AF350330), Tomato yellow leaf curl Thailand virus (TYLCTHV, AY514630) and East African cassava mosaic Zanzibar virus (EACMZV, AF422174). Recombination analysis was done using a recombination detection software, RDP version 2.0 .

\section{RESULTS}

\section{Symptoms and sap inoculation}

Symptoms of a begomovirus-infected honeysuckle plant collected in Kobe, Hyogo prefecture, are shown in (Fig. 1). They consist of yellowing of veins, at times mosaic and/ or yellow mottle on the leaves resulting in honeysuckle yellow vein mosaic disease. Results of sap inoculation are presented in Table 1. HY12 was found to be mechanically transmissible to $N$. benthamiana while FK1, OT2 and SP1 were not. $N$. benthamiana infected with the HY12 developed mild symptoms (data not shown), yet were positive for 
systemic viral infection on analysis by PCR. Attempts to transmit the viruses to $N$. tabacum by sap inoculation were not successful.

\section{DNA-A sequence determination and analyses}

The complete DNA-A nucleotide sequence of HY12 was determined. It comprised 2763 nucleotides (AB178948) and a genome organization similar to that of other monopartite begomoviruses with two open reading frames ORFs [AV1 (CP) and AV2] in the virion sense strand and four in the complementary sense strand (AC1, AC2, AC3 and AC4). The intergenic region (IR) separated the virion and complementary sense genes and contained a putative stem loop structure with the conserved nonanucleotide sequence 5'-TAATATTAC-3' that is characteristic of the Geminiviridae in the loop. The TATA boxes were identified in the IR sequence at nucleotides, 259-262.

Alignment of the retrieved complete DNA-A nt sequences with those from the DNA data bases revealed a high degree of variability ranging from $42 \%$ to $89 \%$ depending on geographical location and or different hosts/diseases. HY12 showed a higher degree of sequence similarity with other begomoviruses found in Japan and rest of Asia than those found in Africa. For instance it shared 74\% with HYVMV, 73\% with HYVMV-OT1 and HYVMV-FK1, 89\% with 74-89 with tobacco leaf curl begomoviruses from Japan, 46\% with AYVCNV-[Hn2] but 42 and 44\% with TbLCZV and EACMZV, respectively (Table 3). Phylogenetic analysis of the complete DNA-A components divided the Japanese begomoviruses into two major groups, the Japanese honeysuckle infecting begomovirses (JHBVs) group and the Japanese Eupatorium infecting begomoviruses (JEpBVs). The

Table 3. Percentage nucleotide or amino acid sequence identities between HY12 and 20 other begomoviruses from Asia and Africa.

\begin{tabular}{lcccccccc}
\hline Virus & DNA" $^{n}$ & IR $^{n}$ & V1 $^{a}$ & V2 $^{\mathrm{a}}$ & C1 $^{\mathrm{a}}$ & $\mathrm{C}^{\mathrm{a}}$ & $\mathrm{C}^{\mathrm{a}}$ & C4 $^{\mathrm{a}}$ \\
\hline EpYVV & 60 & 48 & 87 & 88 & 85 & 68 & 77 & 80 \\
EpYVV-[MNS2] & 59 & 52 & 87 & 85 & 86 & 70 & 76 & 79 \\
EpYVV-[Yamaguchi] & 60 & 51 & 87 & 84 & 86 & 70 & 78 & 77 \\
HYVMV-OT1 & 73 & 92 & 88 & 91 & 92 & 82 & 82 & 86 \\
HYVMV-FK1 & 73 & 92 & 86 & 91 & 93 & 83 & 83 & 84 \\
HYVMV-OT2 & 74 & 92 & 88 & 91 & 93 & 82 & 84 & 84 \\
HYVMV & 74 & 62 & 88 & 90 & 93 & 84 & 84 & 85 \\
TbLCYV & 74 & 64 & 88 & 91 & 92 & 91 & 90 & 78 \\
TbLCJV-[JP2] & 89 & 87 & 91 & 85 & 94 & 81 & 81 & 89 \\
TbLCJV-[JP3] & 89 & 88 & 92 & 84 & 95 & 81 & 81 & 91 \\
TbLCJV & 88 & 64 & 91 & 91 & 95 & 81 & 81 & - \\
AYVCNV-[Hn2] & 46 & 45 & 47 & 57 & 58 & 60 & 69 & 69 \\
ToLCTV & 47 & 48 & 44 & 75 & 58 & 58 & 68 & 74 \\
TLCYNV-[Y3] & 45 & 49 & 47 & 60 & 51 & 57 & 66 & 59 \\
TYLCTHV & 45 & 47 & 45 & 64 & 58 & 55 & 66 & 70 \\
TYLCCNV-Tb[Y5] & 44 & 47 & 42 & 59 & 55 & 58 & 69 & 73 \\
AYVSLV & 41 & 43 & 42 & 63 & 58 & 53 & 64 & 73 \\
MYVV-[Y47] & 41 & 48 & 44 & 55 & 55 & 55 & 64 & 69 \\
EACMZV & 44 & 45 & 41 & 53 & 50 & 53 & 66. & - \\
TbLCZV & 42 & 53 & 41 & 65 & 51 & 52 & 66 & - \\
\hline
\end{tabular}

" Nucleotide sequence identity. " Amino acid sequence identity. 
former was further subdivided into two subgroups namely Japanese honeysuckle infecting begomoviruses subgroup I (JHBV1) and the Japanese tomato infecting tobacco begomoviruses, herein referred to as Japanese honeysuckle infecting begomoviruses subgroup II (JHBV2). The naming of the subgroups was based on the fact that all tobacco and tomato infecting begomoviruses in Japan pass the winter in honeysuckle. The JHBV1 comprise HYVMV-OT1, HYVMV-FK1, HYVMV-OT2 and TbLCYV while JHBV2 comprised HY12, TbLCJV-[JP2], TbLCJV-[JP3] and TbLCJV (Fig. 2). The begomoviruses from China, Taiwan and Thailand were clustered together and so were those from Africa. Hosts also played a big role in the separation of the viruses, Eupatorium geminiviruses were clearly separated from those of honey suckle and tobacco (Fig. 2).

A detailed analysis of the aligned CP nt as well as the deduced amino acid (aa)

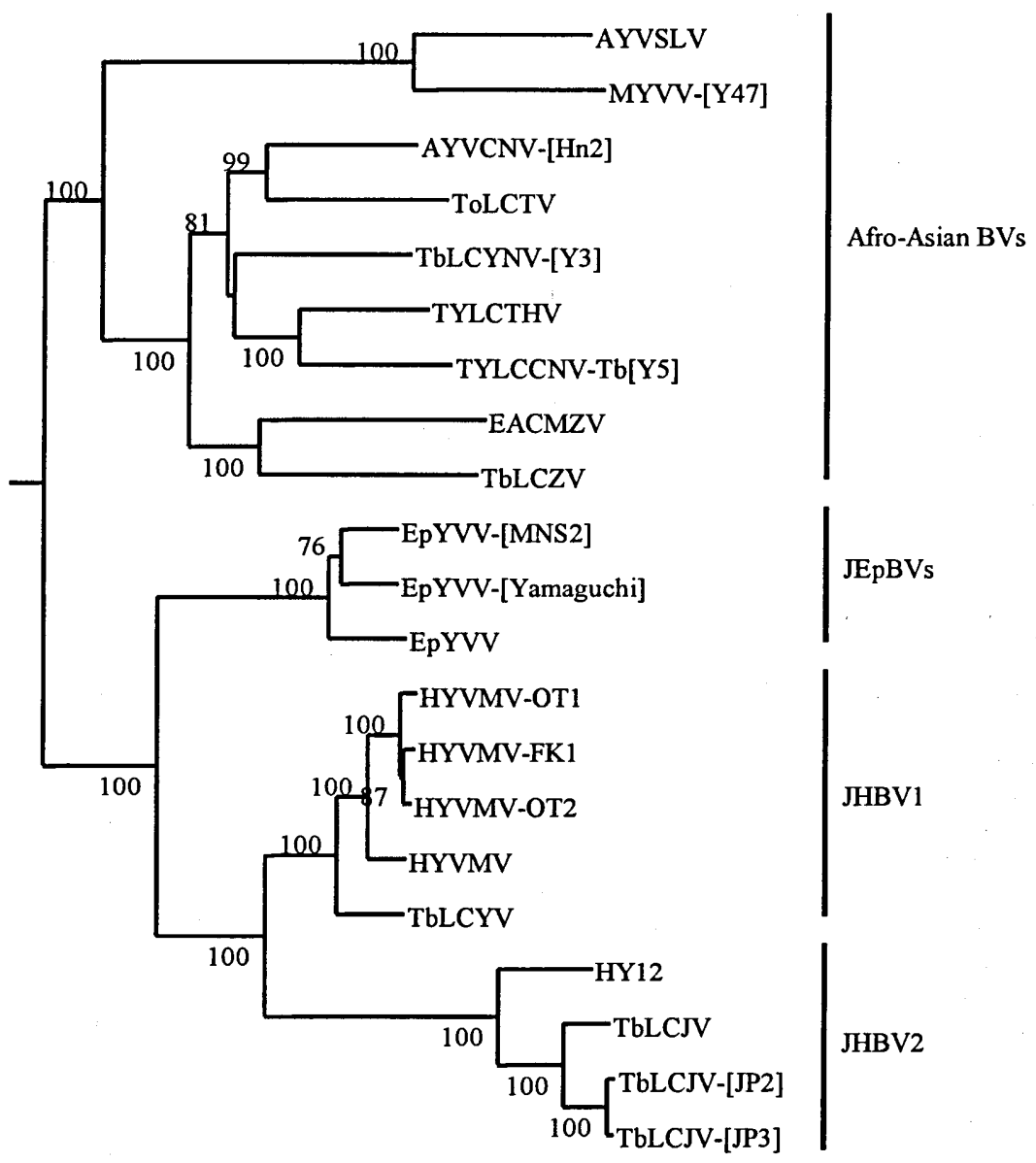

Fig. 2. Phylogenetic tree generated from alignment of full-length DNA-A nucleotide sequences of HY12 and 20 other honeysuckle, tobacco, Eupatorium and other Asian, and African begomoviruses. 
sequences revealed that the 5' terminal and the core region was the most conserved area of the CP in all begomoviruses compared. Furthermore, the HY12 shared a high degree of sequence identity (87-92\%) with the Japanese begomoviruses and less than 50\% with those found in rest of Asia and Africa. Phylogenic analysis of CP aa sequences generated a tree structure in which HY12 was clustered alone but more related to JHBV2 than to JHBV1 (Fig. 3).

When the IR nt sequences were compared, HY12 shared a high percentage (92\%) with HYVMV-OT1, HYVMV-OT2 but HYVMV-FK1 isolates and 64-87\% with JHBV2. Other begomoviruses from rest of Asia and Africa compared poorly with HY12. The IR had the grossest variation of the whole DNA-A component.

A comparison of the $\mathrm{C} 1$ sequences revealed that HY12 shared a higher degree (92-95\%) of sequence identity with JHBV1 and JHBV2 than with those found in the rest

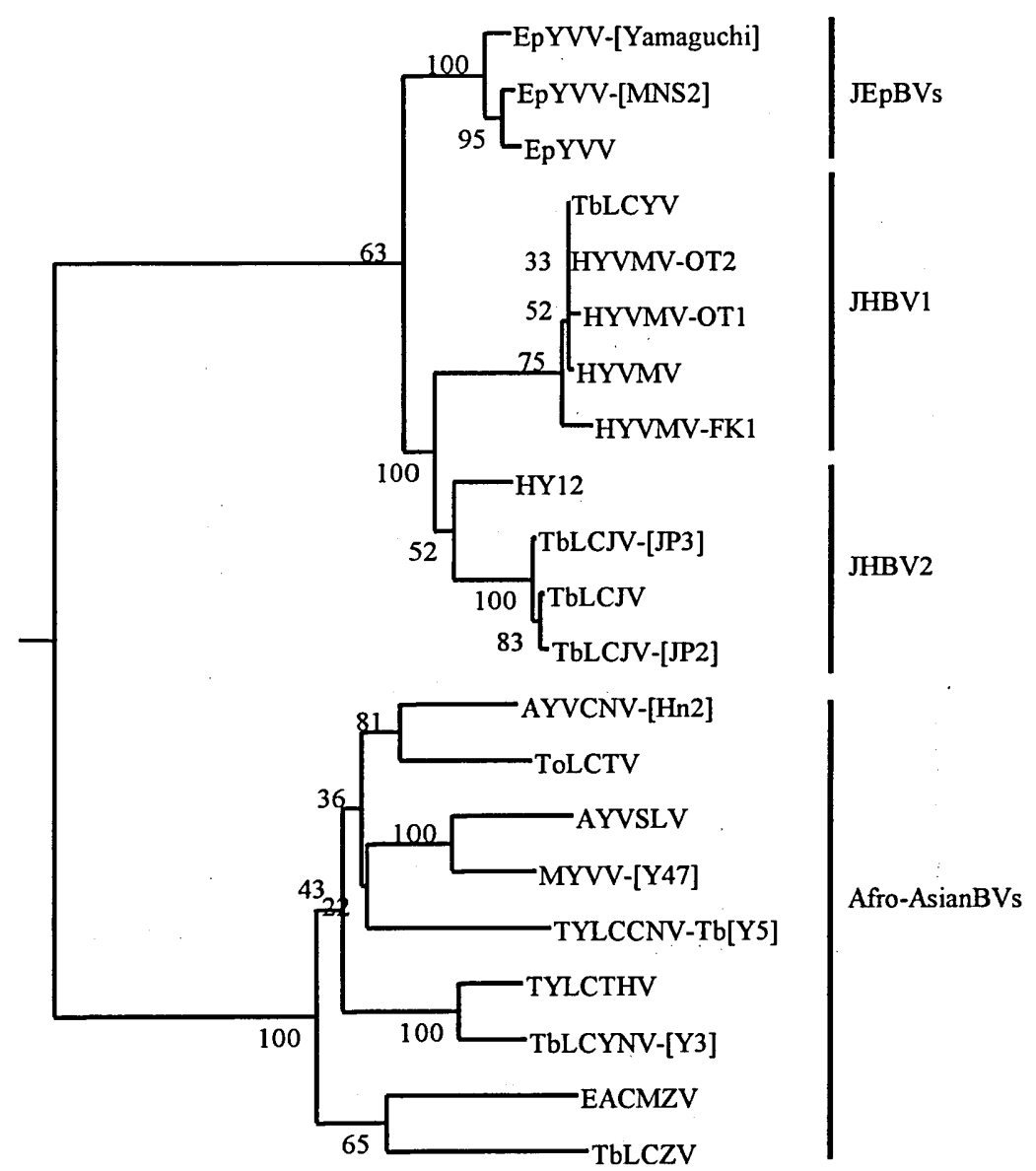

Fig. 3. Phylogenetic tree generated from $\mathrm{CP}$ amino acid sequence alignments of HY12 and 20 other honeysuckle, tobacco, Eupatorium and other Asian and African begomoviruses. 
of Asia and Africa. Generally, the $\mathrm{C} 1$ sequences of Japanese begomoviruses were more related compared to those from the rest of Asia and/or Africa. Phylogenetic analysis of the $\mathrm{C} 1$ aa sequences revealed a tree structure in which HY12 was clustered with JHBV2 (Fig. 4).

When individual encoded proteins were compared, the highest amino acid sequence similarity was between HY12 and TbLCJV with 91\% CP, 91\% V2, 95\% C1, 81\% C2 and C3. Generally, among the Japanese begomoviruses the CP was the most conserved sequence of the genome followed by $\mathrm{C} 1$ and $\mathrm{C} 4$ in that order. It is interesting to note that the $\mathrm{CP}$ of HY12 was most related to JHBV2 than to JHBV1 (Table 3). The contrast is true for the IR, which was in addition found to be most diverse part of the begomovirus genome.

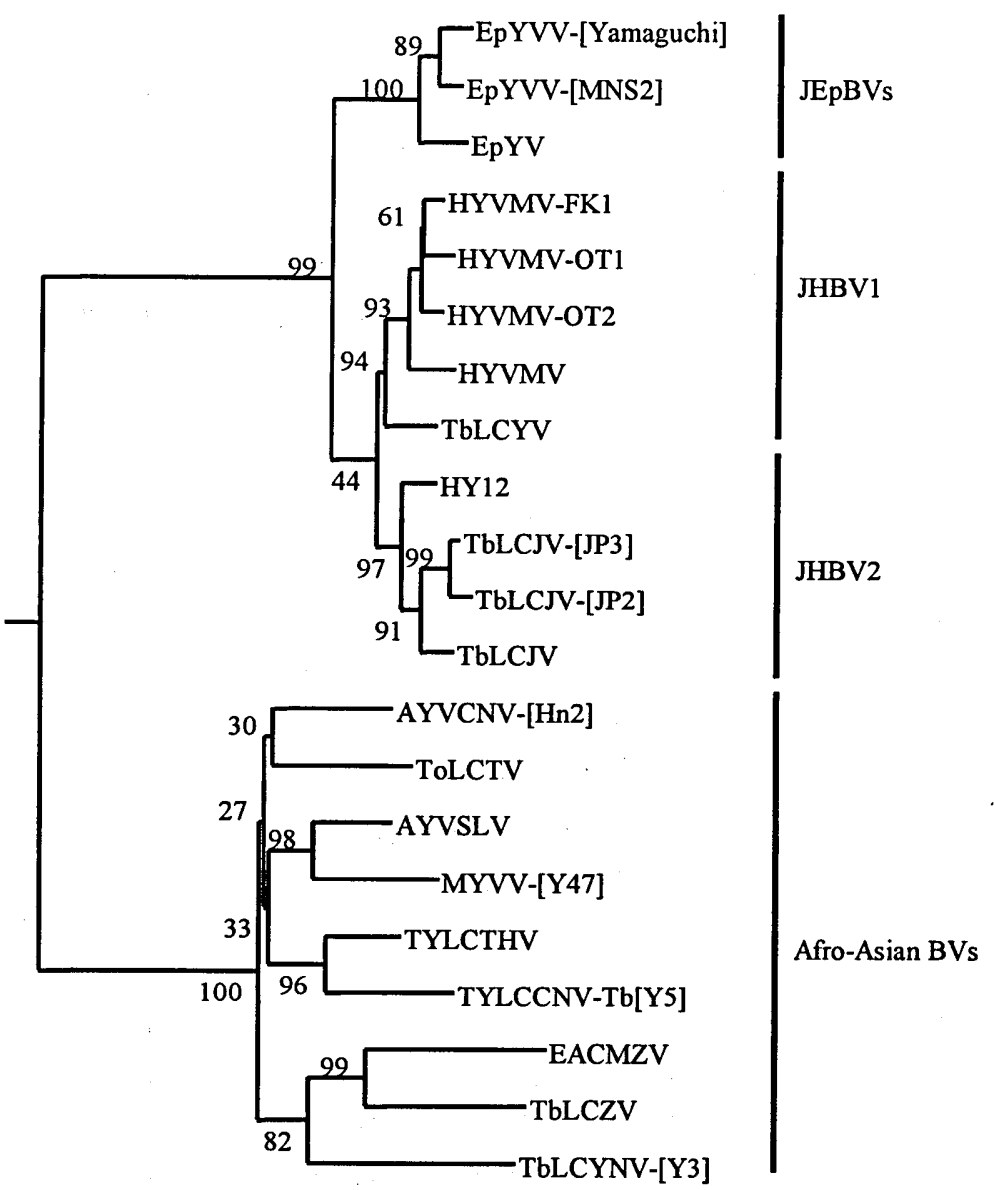

Fig. 4. Phylogenetic tree generated from $\mathrm{Cl}$ amino acid sequence alignments of HY12 and 20 other honeysuckle, tobacco, Eupatorium and other Asian and African begomoviruses. 


\section{DNA $\beta$ sequence determination and analysis}

The complete satellite DNA of HY12 was determined and found to be a recombinant/deletion mutant with 1262 nucleotides (AB182263). The molecule had a satellite conserved region (SCR), typical of the Geminiviridae family containing a 5'-TAATATTAC-3' motif in the stem loop, the $\mathrm{Cl}$ gene and adenine- (A) rich region. The molecule was closely related (80-83\%) to that of honeysuckle yellow vein mosaic disease (HYVMDA, AJ316140) except for the following additions, deletions and recombinations with unknown donors which were certainly not viral in origin:

$$
\begin{aligned}
& \text { HY12 } \beta \quad: 1-89 \text {. .152-216. . . 254-271 . . 612-721 . . 824-867 . . 987-1078. . . } \\
& \text { 1201-1262. } \\
& \text { HYVMDA : 1-90 . . 156-200 . . 239-555 . . 596-706 . . 810-853 . . } 97 \text {-1066. . . } \\
& \text { 1283-1344. }
\end{aligned}
$$

The numbers (range) show areas where HY12 $\beta$ has high sequence homology with HYVMDA while dotted lines represent areas where HY12 $\beta$ has unrelated sequences from unknown source.

\section{Recombination in the DNA-A of HY12 sequence}

HY12 had significant as well as several insignificant recombination events with a major one (762-1853 nt) starting from the core region of the CP spanning the entire $\mathrm{C} 3$, $\mathrm{C} 2$ and part of $\mathrm{C} 1$ (C-terminal). In this event $\mathrm{HY} 12$ sequence formed part of two sequences, TbLCJV-[JP3] and TbLCYV appearing as major and minor parents, respectively. Two events, one (1871-2316 nt) within the $\mathrm{C} 1$ but covering half of $\mathrm{C} 4$ and the other, (2505-14) starting at the N-terminal of $\mathrm{C} 1$ and covering almost the entire IR were also identified. Both events involved TbLCJV as a minor donor while the major parent was unknown.

\section{DISCUSSION}

The results of this investigation in which HY12 was sequenced and compared with other begomoviruses from the databases demonstrate that the isolate is a new distinct previously unrecognized begomovirus. The sap inoculation experiment revealed that HY12 could be transmitted to $N$. benthamiana and that it was not possible to transmit the isolate to tobacco using this means. This coupled with the fact that HY12 induced different symptoms not similar to those induced by HYVMV-FK1, HYVMV-OT1 or HYVMV-OT2 in honeysuckle, implies that HY12 is somehow, somewhere different from the other three isolates. Apparently, this could be due to DNA $\beta$, which was not retrieved from the other three isolates despite repeated attempts to do so. DNA $\beta$ has been shown to modulate symptoms with a conserved coding region referred to as $\beta \mathrm{C} 1$. Whether or not this is true remains to be seen.

Comparison of the nucleotide sequences of HY12 with those from the databases, explored their relationship in great detail. It was shown that HY12 shares a high degree of DNA-A nt as well as CP aa sequence homology with JHBV2 but only a small percentage with JHBV1. In contrast, HY12 shared a high degree of IR sequence homology (92\%) with JHBV1 but only $64-88 \%$ with JHBV2. This can be attributed to a recombination event 
detected in and covering the CP, C3, C2 and part of C1 and involving TbLCJV-[JP3] and TbLCYV as major and minor parents, respectively. However, HY12 CP varied significantly from those found outside Japan. When a complete DNA-A of HY12 was carefully examined different blocks of the sequence had different affinities indicating that genetic recombination had occurred. For instance, the CP of TbLCJV-[JP2] and TbLVJV-[JP3] shared $>90 \%$ but the percentage of their IR sequences shared was very low. It has been shown that IR sequences of begomoviruses give the most sensitive indication of the extent of viral similarity and difference (Padidam et al., 1995) because it contains the presumed Rep binding site (Harrison and Robinson, 1999).

Padidam et al. (1995), observed that strains of anyone virus should share $>90 \%$ of their DNA-A sequence, later, Mayo and Pringle (1998) stated that, they should share $>$ $90 \%$ of their CP sequences in addition. However, the multiplicity of variants due to recombination and other factors associated thereto, increasingly complicate and consequently harden the decision on whether two virus isolates should be considered strains or distinct viruses (Zhou et al., 2001). In conclusion, sequence analyses results have clearly demonstrated that HY12 is a new previously unrecognized begomovirus, a strain of HYVMV.

\section{ACKNOWLEDGEMENTS}

We thank Mr. Hong-Soo Choi of the National Institute of Science and Technology, Suwon, South Korea for help with sequencing. This work was funded by the Japan Society for the Promotion of Science, Postdoctoral Fellowship for Foreign Researchers.

\section{REFERENCES}

Briddon, R. W. and P. G. Markham 1994 Universal primers for the PCR amplification of dicot-infecting geminiviruses. Mol. Biotech., 1: 202-205

Briddon, R. W. and P. G. Markham 1995 Geminiviridae. In: Virus taxonomy: Sixth report of the International Committee on Taxonomy of Viruses, pp. 158-165. Murphy, F. A., Fauquet, C. M., Bishop, D. H. L., Ghabrial, S. A., Jarvis, A. W., Martelli, G. P., Mayo, M. A., Surmers, M. D., eds. Springer Verlag, Wien and New York

Briddon, R. W., S. E. Bull, S. Mansoor, I. Amin and P. G. Markham 2002 Universal Primers for the PCR-Mediated Amplification of DNA $\beta$ : a molecule associated with some monopartite begomoviruses. Mol. Biotech., 20: 315-318

Dellaporta, S. L., J. Wood and H. B. Hicks 1983 A plant DNA minipreparation: Version II. Plant. Mol. Biol. Rep., 1: 19-21

Fauquet, C. M., D. P. Maxwell, B. Gronenborn and J. Stanley 2000 Revised proposal for naming geminiviruses. Arch. Virol., 145: 1743-1761

Fauquet, C. M. and J. Stanley 2003 Geminivirus classification and nomenclature: progress and problems. Ann. Appl. Biol., 142: 165-189

Harrison, B. D. and D. J. Robinson 1999 Natural genomic and antigenic variation in whitefly-transmitted geminviruses (begomoviruses). Ann. Rev. Phytopathol., 37: 369-389

Ikegami, M., T. Osaki and T. Inouye 1987 Single stranded DNA in tobacco curl virus. Ann. Phytopath. Soc. Jpn., 53: 269-273

Mayo, M. A. and C. R. Pringle 1998 Virus taxonomy-1997. J. Gen. Virol., 79: 649-657

Onuki, M. 2003 Studies on Molecular Identification of Begomoviruses isolated in Japan. Ph.D Thesis, Kyushu University, Japan, $171 \mathrm{pp}$.

Padidam, M., R. N. Beachy and C. M. Fauquet 1995 Classification and identification of geminviruses using sequence comparisons. J. Gen. Virol., 76: 249-263 
Rybicki, E. P. 1994 A phylogenetic and evolutionary justification for three genera of geminiviridae. Arch. Virol., 139: 49-77

Saitou, N. and M. Nei 1987 The neigbhour-joining method: A new method for reconstructing phylogenetic trees. Mol. Biol. Evol., 4: 406-425

Sambrook, J., E. F. Fritsch and T. Maniatis 1989 Molecular Cloning: A Laboratory Manual, 2nd edn. New York: Cold Spring Harbor Laboratory

Saunders, K., J. D. Bedford, R. W. Briddon, P. G. Markham, S. M. Wong and J. Stanley 2000 A unique virus complex causes Ageratum yellow vein disease. Proc. Natl. Acad. Sci. USA, 97: 6890-6895

Saunders, K., A. Lucy and J. Stanley 1991 DNA forms of the geminivirus African cassava mosaic virus consistent with a rolling-circle mechanism of replication. Nucl. Acids Res., 19: 2325-2330

Were, H. K. 2001 Serological and molecular characterization of begomoviruses infecting cassava (Manihot esculenta Crantz) in Africa. Ph.D Thesis, University of Hanover, Germany, $187 \mathrm{pp}$.

Zhou, X. P., Y. Xie and Z. K. Zhang 2001 Molecular characterization of a distinct begomovirus infecting tobacco in Yunnan, China. Arch. Virol., 146: 1599-1606 